Стоян А.

Інструменти оцінювання доказів в адміністративному процесі

DOI: $10.35774 /$ app2021.03.090

УДК: 342.92

\title{
Анна Стоян,
}

аспірант кафедри адміністративного та фінансового права, Національного університету «Одеська юридична академія» ORCID: https://orcid.org/0000-0001-9176-5516

\section{ІНСТРУМЕНТИ ОЦІНЮВАННЯ ДОКАЗІВ В АДМІНІСТРАТИВНОМУ ПРОЦЕСІ}

Постановка проблеми. Прагнення України відповідати стандартам демократичної держави стало лейтмотивом численних зрушень у вітчизняному правовому полі, зокрема у сфері адміністративного судочинства. Постійне вдосконалення доказування як одного з иеентральних інститутів кожного процесуального права $\epsilon$ запорукою гармонійного розвитку усієї судової системи. Саме тому серед науковиів не вгасає інтерес до зазначеної сфери дослідження як загалом, так і принагідно кожного зі складових етапів. У статті розглянуто останній етап доказування - оцінювання доказів, щуо набуло актуальності у зв'язку із залученням зарубіжного інструментарію у вигляді стандартів доказування для ї̈ реалізації. Така тенденџія, з одного боку, збільшила поле потенційних наукових розвідок, а з іншого - утворила пробільність та неповноту знань як на теоретичному, так і праксеологічному рівнях щзодо поняття, місия й особливостей функиіонування стандартів доказування, та способу взаємодії останніх із концепцією «внутрішнього переконання». Метою статті є оновлення фундаментального знання про способи оцінки доказів суддею та надання галузевої дефініцій стандартів доказування, а також визначення поняття та видів інструментів оцінки доказів. Використані методи. За допомогою порівняльно-правового та формально-юридичного методів досліджено сутність поняття доказування як загального, так і галузевого поняття, а також оцінки доказів як заключного етапу доказування в адміністративному процесі. Формально-юридичний метод став основою створення дефініції стандартів доказування й інструментів оцінки доказів у адміністративному процесі. Історико-правовий метод дозволив простежити генезу способів об 'єктивізації внутрішньої та зовнішньої сторони оцінки доказів. Використання методів гіпотези, припущення та моделювання допомогли створити пропозищії щодо закріплення стандарту доказування у Кодекс адміністративного судочинства як додаткового інструменту об 'єктивізації розумового аспекту оцінки доказів суддею. Результати. Встановлено, щзо серед вчених відсутні істотні розбіжності у розумінні як самого поняття доказування, так і адміністративно-процесуального доказування. Визначено, щзо оцінка доказів має двокомпонентну структуру - внутрішню (логічну) та зовнішню (правову). 3 урахуванням менших можливостей об 'єктивізації внутрішньої сторони оцінки доказів наведено способи мінімізації помилок при реалізації останннього етапу доказування. Доведено, щзо комбінування вимог на посаду судді та положень нормативно правових актів повинні поєднуватися із використанням як вітчизняної концепиії (за внутрішнім переконанням), так $i$ зарубіжного (стандарти доказування) оціночного інструментарію задля ухвалення справедливо рімення у справі. Запропоноване визначення стандартів доказування, інструментів очінки доказів та їх видів в адміністративному процесуальному праві разом із пропозиціями внесення змін та доповнень до Кодексу адміністративного судочинства Украӥни. Висновок. Істотні особливості оцінки доказів у адміністративному процесі у порівнянні з іншими процсуальними галузями права відсутні. Наразі різниться полягає у констатації факту наявності або відстуності законодавчої регламентаиії стандарту доказування у профільному нормативно-правовому акті. Оцінювання доказів має двокомпоненту структуру, а саме: зовнішньо-правову та внутрішньо-логічну частини. Встановлено, щзо внутрішня складова потребує залучення додаткових інструментів очінювання доказів через ї̈ переважно неправову природу. Отже, найкращзим способом об'єктивізаџії внутрішньої складової очіночної діяльності є синтез спеціалізованих вимог у процесі відбору на посаду судді та вдосконалення законодавчих механізмів контролю за судовою гілкою влади у поєднанні із закріпленням триступеневої градаиї стандартів доказування у Кодексі адміністративного судочинства Украӥни як практичного інструментарію в руках суддів. Під інструментами оцінювання доказів пропонується розуміти шлях або спосіб формування такого стану внутрішнього переконання, яке дає змогу ухвалити справедливе рішення по справі.

Ключові слова: доказування, оцінювання доказів, суддя, внутрішнє переконання, стандарти доказування.

Стоян А.

Инструменты оценки доказательств в административном процессе

(c) Анна Стоян, 2021 
Постановка проблемы. Постоянное совершенствование доказывания как одного из иентральных институтов каждого прочессуального права является залогом гармоничного развития всей судебной системы. Статья посвящена разработке последнего этапа доказывания - оченки доказательств, что усилило свою актуальность в связи с привлечением зарубежного инструментария в виде стандартов доказывания для ее реализации. Такая тенденция с одной стороны увеличила поле потенциальных научных исследований, а с другой образовала пробель и неполноту знаний на теоретическом и праксеологическом уровнях относительно понятия, места и особенностей функиионирования стандартов доказывания, и способа взаимодействия последних с кониепџией «внутреннего убеждения». Целью статьи является обновление фундаментального знания о способах оценки доказательств судьей и предоставление отраслевой дефиниций стандартов доказывания, а также определение понятия и видов инструментов оценки доказательств. Результать. Установлено, что среди ученых отсутствуют существенные различия в понимании как самого понятия доказывания, так $u$ административно-процессуального доказывания. Определено, что оценка доказательств имеет двокомпонентную структуру - внутреннюю (логическую) и внешнюю (правовую). С учетом различных возможностей объективизации каждой из сторон оченки доказательств, приведены способы минимизации ошибок при оценке доказательств. Доказано, что наилучшим способом поднятия уровня правосудия выступает сочетания ряда приемов, а именно сочетание требований на должность судьи и положений нормативно-правовых актов, использование не только отечественного (по внутреннему убеждению), но и зарубежного (стандарты доказывания) оченочного инструментария для принятия справедливого решения по делу. Предложено определение стандартов доказывания, инструментов оценки доказательств и их видов в административном проиессуальном праве вместе с предложениями о внесении изменений и дополнений в Кодекс административного судопроизводства Украины. Выводы. Существвенные особенности оиенки доказательств в административном процессе по сравнению с другими прочесуальнимы отраслями права отсутствуют. Оиенка доказательств имеет двокомпонентною структуру, а именно внешне-правовую и внутренне-логическую. Установлено, что внутренняя составляющая требует привлечения дополнительных инструментов оценки доказательств через ее преимущественно неправовую природу. Лучшим способом объективизации внутренней составляющей оценочной деятельности является синтез специализированных требований при отборе на должность судьи и совершенствование законодательных механизмов контроля за судебной ветвью власти в сочетании с закреплением трехступенчатой градаџии стандартов доказывания в Кодексе административного судопроизводства Украинь.

Ключевые слова: доказывания, оченка доказательств, судья, внутреннее убеждение, стандарть доказывания.

\section{Stoian $A$.}

The evaluating tools of the evidence in the administrative process

Problem statement. Ukraine's desire to meet the standards of a democratic state has become the leitmotif of numerous changes in the legal field of the state, especially in the field of administrative justice. The constant improvement of evidence as one of the central institutions of every procedural branch of law is the key to the harmonious development of the entire judicial system. This article is devoted to the study of the last stage of proof - the evaluation of evidence, which has become relevant in connection with the involvement of foreign evaluating tools in the form of standards of proof. This trend, on the one hand, has increased the field of potential scientific research and, on the other, created gaps and incomplete knowledge at both theoretical and praxeological levels regarding the concept, place and features of the standards of proof. The purpose of the article is to update the fundamental knowledge about the judge's evaluating ways of the evidence in the administrative process and to provide a sectoral definition of standards of proof, and also evaluating tools and the kinds of tools. Methods. With the help of comparative-legal and formal-legal methods the essence of the concept of proving both general and branch concept, and also an estimation of proofs as a final stage of proving in administrative process is investigated. Incidentally, the formal-legal method became the basis for creating a definition of standards of proof and tools for evaluating evidence in the administrative process. The historicallegal method allowed us to trace the genesis of ways to objectify the internal and external side of the evaluation of evidence. The use of hypothesis, assumption, and modeling techniques has helped to create proposals for enshrining the standard of proof in the Code of Administrative Procedure as an additional tool to objectify the mental aspect of a judge's evaluation of evidence. Results. It is established that among scientists there are no significant differences in understanding both the concept of proof and administrative-procedural proofing. The decision's ability to correspond the criteria of fairness, legality and reasonableness depends on the proper evaluation activities of the judge. It was established that the evaluation of evidence includes two components: logical and normative, which have different ways of objectification. The ways how to objectificate the logical aspects of evaluating evidence were indicated. Such kind of activities should involved constant improving of the legal norms, increasing the requirements for potential judges and synchronously applying the concept of inner conviction and the standards of proof. Besides that the standards of 
proof should be allocated as additional instrument of objectification the psychological process of the judge's evaluating activity in administrative process. The ways of describing the definition of standard of proof were also analyzed. The definition of the standard of proof in administrative process were proposed. The propositions of changes and additions to the Code of Administrative Procedure of Ukraine have been formed. Conclusions. The evidence's evaluation is being not influenced by features of the administrative process. The difference between the evaluation of evidence in different processes is the presence or non-existing of a legally established standard at the level of the relevant law. The party's ability to evaluate evidence in the proper way is the key for realization reasonable procedural deadlines. The judge's evaluation of the evidence has a greater impact on the intermediate or final decision, than another one else. The structure of the evidence's evaluation include inner and outer sides. Every of this sides are being different ability to be understood by other people. The inner part are being contained less objectification's ability, but scientists continue to develop useful ways in order to control the process of accepting the decision and here some of them: 1) creating high requirements for the potential judge during the selection of professional corps of judges; 2) improving the judicial norms; 3) implementation of the standards of proof as an additional tool of evidence's evaluation, which assist to create internal conviction.

Keywords: evidence, evaluation of evidence, judge, inner conviction, standards of proof.

Постановка проблеми. Україна як демократична країна приділяє велику увагу розвитку та вдосконаленню судової влади, зокрема адміністративного судочинства, яке з огляду на притаманні йому особливості потребує додаткових гарантій у частині доказової діяльності задля ухвалення справедливого рішення у справі. Оскільки доказування, як і будь-яка діяльність, складається з послідовних взаємопов'язаних етапів, то прицільна увага кожному з них формує досконалий процесуальний механізм, що сприяє утвердженню верховенства права та формує позитивний імідж нашої країни в очах світової спільноти. Тому фокус поточного дослідження зосереджений саме на оцінці доказів як заключному етапі доказування у адміністративному процесі та зумовлений тенденціями щодо імплементації зарубіжних інструментів, зокрема стандартів доказування як додаткового способу об'єктивізації суддівського розсуду в процесуальні галузі права. Обрана тематика має високий рівень актуальності у зв’язку з частковою пробільністю та відсутністю фундаментальних досліджень у рамках адміністративного процесуального права саме 3 окреслених питань.

Аналіз останніх досліджень і публікацій. Загалом доказування як один із центральних інститутів кожного процесуального права був предметом дослідження видатних вчених у різних галузях, серед яких С. В. Ківалов, А. Ю. Осадчий, Д. А. Козачук, І. В. Гловюк, Ю. П. Аленін, В. Ф. Бойко, Ю. М. Грошевий, С. В. Курильов, Б. Т. Матюшина, Т. В. Степанова, А. І. Трусова, М. К. Треушнікова, В. В. Бабенко, А. Я. Вишинський, А. Г. Коваленко, Л. М. Ніколенко, І. В. Решетнікова та ін. Особливу увагу дослідженню стандартів доказування приділяли А. М. Безносюк, А. С. Степаненко, Х. Р. Слюсарчук, А. Г. Карапетов, А. С. Косарєв, Г. Р. Крет та ін.

Мета дослідження полягає у вдосконаленні системи знань про суддівську оціночну діяльність 3 урахуванням стандартів доказування в рамках адміністративного процесу.

Новизна дослідження полягає у запровадженні поняття «інструменти оцінки доказів» та наданні галузевої дефініції стандартів доказування як оціночного інструментарію адміністративного процесу.

Завдання дослідження: 3'ясувати сутність доказування як загального та галузевого поняття; окреслити особливості, суб'єктний склад та складові компоненти оцінки доказів як заключного етапу адміністративного процесуального доказування; проаналізувати способи впливу на внутрішню (логічну) сторону оцінювання доказів під час відправлення правосуддя; надати дефініцію інструментам оцінювання доказів, стандартам доказування та вказати види оціночного інструментарію в адміністративному процесі; сформувати пропозиції щодо внесення змін та доповнень до нормативно-правових актів.

Виклад основного матеріалу дослідження. Переважна більшість вчених погоджуються з тим, що доказування потрібно розглядати як процес пізнання - чуттєвого (безпосереднього) і раціонального (опосередкованого) $[1 ; 2]$. Опираючись на основоположні засади гносеології, доказування можна представити як специфічну методологію процесуального характеру, яка полягає у пізнанні уповноваженими законом суб'єктами обраного об'єкта [3, с. 8]. Також процес доказування описують як складну діяльність, яка розпадається на окремі, пов'язані між собою пізнавальні акти щодо вирішення необхідних питань та встановлення обставин у справі [4, с. 113]. Інакше кажучи, доказування завжди є певною діяльністю визначених учасників того чи іншого процесу, яка має відповідну мету. Сама теорія доказування охоплює здобутки логіки, психології, теорії інформації і поширюється на всі суспільні відносини та явища зовнішнього світу, які тим або іншим чином пов’язані з процесом доказування [4, с. 9]. 
С. В. Ківалов, А. Ю. Осадчий, О. В. Закаленко визначають адміністративне процесуальне доказування як врегульовану адміністративно-процесуальними нормами діяльність суду та учасників адміністративного процесу з приводу збирання і закріплення, дослідження та оцінювання доказів, що мають значення для вирішення адміністративної справи [5]. Загалом, серед вчених немає розбіжностей у розумінні суті доказування як взагалі, так і безпосередньо адміністративного-процесуального доказування. Однак з огляду на те, що теорія доказування поширюється на безліч різноманітних відносин важливо звернути увагу на специфічні риси саме адміністративного процесу, які вирізняють притаманне йому доказування 3-поміж інших процесуальних галузей права.

Першою такою особливістю варто назвати форму процесу, яка, власне, і визначає хід розгляду справи та доказову активність сторін. Так, наприклад, змагальна форма в чистому вигляді притаманна цивільному та господарському судочинству, що підтверджується Постановою КГС ВС від 14.12 .2018 у справі № 914/809/18, яка містить такі роз’яснення: «суд не може збирати докази, що стосуються предмета спору, з власної ініціативи, крім витребування доказів судом у випадку, коли він має сумніви у добросовісному здійсненні учасниками своїх процесуальних прав або виконання обов'язків щодо доказів, відповідно до частини четвертої статті 74 ГПК України» [6]. Отже, змагальна форма судочинства покладає тягар доказування переважно на сторони, за винятком окремих конкретно визначених випадків. Навпроти, в адміністративному процесі діє змішана форма, яка, незважаючи на звичну активність сторін наділяє суд можливістю за власною ініціативою або клопотанням учасників витребувати докази, частково впливаючи на перебіг справи та виконуючи так звану інквізиційну функцію [5].

Друга визначальна риса - початково неоднаковий процесуальний статус сторін, що примушує будувати «механізм судового розгляду з орієнтацією на невладну сторону спору» [7, с. 137-145]. Така побудова процесу створює надійний базис для реалізації принципу рівності у випадках, коли очевидні неоднакові стартові процесуальні можливості сторін. Третя ознака стосується функціонування галузевого принципу «офіційного з'ясування всіх обставин у справі» [8]. О. В. Кротюк принцип офіційного з'ясування позначає як формально визначену і юридично закріплену сукупність основоположних ідей і положень, які характеризують активну участь суду в стимулюванні сторін до подання доказів у справі, а також здійснення безпосереднього виявлення та витребування доказів, що мають значення для встановлення істини у справі та прийняття законного й обгрунтованого рішення [9, с. 7]. Принагідно вказати, що принцип «офіційного з'ясування всіх обставин у справі» розуміють також як галузеве уточнення більш широкої за змістом ст. 129 Конституції України в якій вказано, що «суддя, здійснюючи правосуддя, є незалежним та керується верховенством права» [4, с. 112]. Так, якщо аналогічний принцип теоретично імплементувати у цивільний або господарський процеси, то фундаментальні вимоги щодо неупередженості та незацікавленості судді в ході судового розгляду було б неодмінно порушено, а принципи змагальності та диспозитивності втратили своє первісне значення [4, с. 113].

Четвертою особливістю є встановлення презумпції правоти заявника в окремих категоріях справ або, інакше кажучи, закріплення тягаря доказування у визначених випадках за суб’єктом владних повноважень. Так, О. М. Бандурка вказує, що для адміністративного процесу, який включає велику кількість різних за змістом проваджень важливе значення, окрім презумпції невинуватості, має презумпція правомірності дій і правової позиції громадянина, що припускає правильність і обгрунтованість його поведінки в стосунках з державними органами та посадовими особами [10, с. 78-79].

Оцінка доказів як заключний етап доказування: поняття, суб'єкти, структура. Хоча виокремлені особливості допомагають відрізнити адміністративний процес від інших галузей права, водночас власне оцінювання доказів як заключний та важливий етап доказування має тотожні риси та складові елементи незалежно від юрисдикції. Єдиний критерій, за яким наразі можливо розрізнити особливості оцінювання доказів у різних процесуальних галузях права, грунтується хіба що на констатації відсутності чи наявності положення, яке б регламентувало вид використовуваного стандарту доказування у профільному нормативно-правовому акті. Так, наприклад Кримінальний процесуальний кодекс України закріпив у ч. 2 ст. 17 найвищий стандарт «поза розумним сумнівом» як поріг впевненості, якого повинен досягнути суддя аби призначити покарання у вигляді позбавлення волі [11]. До речі, в такому випадку вмотивованість такого високого стандарту можливо пояснити через потенційні наслідки, що очікують на особу у разі засудження. До Господарського процесуального кодексу України були внесені зміни, які трансформували ст. 79 у «Вірогідність доказів», виклавши її зміст у формі, яка відповідає стандарту доказування «баланс вірогідностей», підкресливши необхідність співставлення судом «версій» сторін (п. 8.12-8.20 [12]). Такий стандарт вважається найнижчим з відомих стандартів під час відправлення правосуддя, адже вимагає подолати по- 
Стоян А.

Інструменти оцінювання доказів в адміністративному процесі

ріг впевненості принаймні на 50\%+1 аби ухвалити рішення на користь однієї зі сторін. Такий невисокий пороговий рівень також можливо пояснити, використавши теорію наслідків: найгірші наслідки в рамках господарського процесу ніколи не прирівняються до кримінальної стигматизації особи.

Отже, аналіз вищезазначених положень свідчить, що законодавець закріпив найбільш типовий стандарт для відповідної галузі, не обмежуючи використання за потребою й інших стандартів доказування. Кодекс адміністративного судочинства України (далі - Кодекс; КАСУ) наразі не містить жодного згадування про стандарт доказування, який мають використовувати судді. Водночас широкий спектр різноманітних правовідносин, які згруповані та представлені у вигляді категорій адміністративних спорів навряд чи можливо узагальнено описати тільки одним єдиним стандартом доказування як найбільш типовим для досліджуваної галузі. Тому, як видається, цілям адміністративного судочинства мають слугувати й бути закріплені у Кодексі одразу декілька стандартів доказування, а саме: «баланс вірогідностей», «очевидні та переконливі докази», «поза розумним сумнівом», адже однозначно виокремити домінантний, типовий стандарт не так легко, як в інших процесах. А особливу увагу в рамках адміністративного судочинства необхідно звернути на механізм підбору належного стандарту доказування залежно від категорії спору, суб'єкта до якого він застосовується та аналізу потенційних індивідуалізованих наслідків для кожної зі сторін.

Водночас повертаючись до дослідження загальних положень оцінювання доказів, необхідно зазначити, що О. Авраменко, невипадково, зосереджуючи увагу переважно на етапі дослідження як «безпосередній діяльності суду та сторін спору, що направлена на вилучення з наявних у справі доказів необхідної та достатньої для вирішення справи кількості інформації», постійно наголошує, що базисом для правильного та своєчасного вирішення адміністративного спору по суті є також подальше оцінювання доказів [4, c. 112]. Так, навіть за умови зразкового проведення процедури дослідження доказів їх частково або абсолютно помилкова оцінка надалі може звести нанівець будь-які процесуальні старання учасників та суду, підриваючи довіру до судової влади як з боку українського суспільства, так і в очах світової спільноти. К. С. Пащенко, опираючись на власний суддівський досвід, вважає, що оцінювання доказів є одним 3 найбільш важливих у структурі доказування та визначає ії як елемент процесу доказування, який охоплює розумову та практичну діяльність судді із встановлення ознак доказів та мотивування висновків щодо їх урахування чи відхилення у справі [13, с. 38]. Науковець також аналізує інші підходи до розуміння поняття оцінки доказів, зокрема як: 1) розумового процесу, який заснований на логічних законах; 2) логічного акту, який виражається в процесуальних діях; 3) психологічній діяльності суб'єкта прийняття рішення, яка відбувається як в логічній, так і процесуальній формах; 4) розумової діяльності суду, яка здійснюється на основі внутрішнього переконання та заснована на всебічному, повному й об'єктивному розгляді всіх обставин справи. Таке різноманіття визначень, найбільш вірогідно, зумовлено неоднозначною природою закріплення оцінювання доказів у ст. 90 КАСУ законодавцем, який вказав лише умови ії реалізації та критерії прийнятності доказів [13, с. 39-40].

Однак навіть незважаючи на велику кількість доктринальних підходів щодо пояснення суті оцінювання доказів, істотні протиріччя у поглядах вчених щодо означеного питання відсутні. Тому навряд чи варто говорити про необхідність законодавчого закріплення такої категорії. Як видається, законодавець, розуміючи загальновживаність поняття «оцінки» та відсутність труднощів у семантико-логічному трактуванні самого терміна, зосередив увагу на способах, умовах та особливостях їі реалізації, що відображено в Кодексі. Отже, підтримуючи вищенаведену логіку вдосконалення процесуальних положень, вважаємо за необхідне закріпити у нормативно-правових актах не стільки визначення оцінювання доказів, а поняття та види інструментів оціночної діяльності. При чому під інструментами оцінювання доказів пропонується розуміти допоміжні елементи об'єктивізації мисленнєвого процесу судді у вигляді стандартів доказування, що застосовуються на шляху формування знання про факти об’єктивної соціальної дійсності, забезпечуючи досягнення та існування такого стану внутрішнього переконання, яке дає зсогу судді ухвалити справедливе рішення по справі.

Водночас правом оцінювати докази володіє не лише суддя, а й сторони адміністративного процесу [14, с. 110]. Залежно від мети та наслідків такої діяльності її можливо розглядати у широкому та вузькому сенсі. Так, у першому випадку оціночну діяльність реалізують зацікавлені учасники процесу з метою розуміння фактичного стану й перспектив судового розгляду, наприклад, для прогнозування наслідків вчинення або утримання від певних процесуальних дій (подання або приховування потенційного доказу). Беззаперечно, правильне оцінювання доказів сторонами полегшує роботу судді, що виражається, наприклад, у скороченні випадків виходу за межі доказування та загалом позитивно впливає на дотримання розумних 
строків під час розгляду справи. У вузькому значенні оцінювання доказів - це вузькоспеціалізована діяльність судді, спрямована на вирішення публічно-правового конфлікту у формі проміжного або підсумкового рішення. Інакше кажучи, оцінка осіб, які беруть участь у справі, є рекомендаційною, а оцінка суду - владною [14, с. 13-14].

Акцентуючи увагу в рамках поточного дослідження саме на суддівському оцінюванні доказів, варто зазначити, що їі метеріалізованим результатом є резолютивна частина рішення, яка «часто не відображає єдність суддівського розсуду» [15]. Наявні розбіжності можливо краще зрозуміти шляхом аналізу структури оцінювання доказів. Так, О. П. Цюпак виокремлює в оцінюванні доказів логічну сторону як розумову діяльність, що недоступна сторонньому оку, та правову складову як таку, що завжди має наслідком вчинення певної процесуальної дії уповноваженим суб'єктом із врахуванням передбачених законом правил [16, c. 184]. К. С. Пащенко також зазначає, що «оцінка доказів не є виключно розумовою, логічною діяльністю, адже вона має зовнішнє вираження у рішеннях і процесуальних діях, а тому оцінка доказів включає внутрішню (логічну) та зовнішню (правову) сторони» [13, с. 40]. В. О. Немченко виокремлює юридичний, психологічний та морально-етичний аспекти в оцінюванні доказів за внутрішнім переконанням [17, с. 402].

Водночас в історичній ретроспективі часто поставало питання про можливість вичерпного, тотального правового регулювання оцінювання доказів з огляду на існування в іï структурі розумового аспекту, який більше є об'єктом дослідження правової психології, аніж суто юридично-прикладним поняттям. Зокрема, С. В. Курильов стверджував, що неможливо регламентувати розумовий процес, який відбувається відповідно до законів мислення за допомогою правових інструментів [18, с. 36-37]. Водночас Б. Т. Матюшин вбачав пряму можливість та необхідність законодавчого закріплення оцінювання доказів, розкриваючи іiї процесуальну форму у вигляді трискладової системи елементів: а) сукупність процесуальних вимог, запропонованих до розумової діяльності з оцінювання доказів; б) процес реалізації цих вимог у ході розумової діяльності суддів з оцінювання доказів; в) процесуальний результат, що відображений у судовому рішенні (ухвалі) [19, с. 8-9]. Л. В. Мелех також підтримує вищезазначену позицію, мотивуючи тим, що оцінювання доказів як логічний акт виявляється в процесуальних діях, а тому піддається у визначених межах правовому регулюванню [20, с. 169].

Отже, презюмуючи наявність двокомпонентної структури оцінювання доказів, а саме: логіко-психологічного та юридико-правового аспектів, варто визнати можливість їхньої законодавчої регламентації, проте з уточненням, що доступна ступінь деталізації кожного з них буде однозначно різною. Так, можливість простежити, проконтролювати та спрогнозувати правову або зовнішню сторону доказування набагато легше, адже iіi результати завжди об’єктивовані. Саме тому поряд з конституційним положенням про самостійність та незалежність судової гілки влади існують численні важелі корекції та впливу на неї, зокрема у формі загальних засад та принципів здійснення правосуддя, контролю з боку Вищої кваліфікаційної комісії суддів України та Вищої ради правосуддя, а також існування права на відвід судді, судовий перегляд рішення на національному й міждержавному рівнях.

Водночас на психологічний аспект оцінювання доказів, який, як правило, призводить до виникнення розбіжностей у суддівському розсуді під час відправлення правосуддя, вплинути набагато важче через його надмірно суб'єктивний та переважно неправовий характер, проте можливо. Саме тому багато теоретиків та практиків все ще конструюють надійні параметри задля більшої об'єктивізації оціночної діяльності судді з метою уніфікації судової практики та утвердження європейських цінностей.

Способи впливу на психологічну складову під час оцінювання доказів суддею. На початковому етапі вітчизняної розробки вказаної проблематики пропонувалися різноманітні шляхи подолання негативних наслідків психологічної складової оцінювання доказів. Так, В. О. Немченко, наголошуючи на важливості пошуку способів уникнення суддівського свавілля при розгляді справи, вбачав вихід у психолого-акмеологічному розвитку особистісно-професійного потенціалу судді, зокрема у формі досягнення професійної майстерності на грунті реалізації творчого потенціалу особистості судді, що набуває особливого значення у процесах формування внутрішнього переконання судді в адміністративному процесі [17, с. 405]. О. П. Цюпак розвиток справедливого адміністративного правосуддя в Україні ілюстрував як комбінування належних процесуальних норм із стандартизованими вимогами, що висуваються до претендентів під час формування високопрофесійного та компетентного корпусу суддів зі стабільним психоемоційним станом та індивідуальними вольовими й розумовими якостями, а також вважав за необхідне враховувати мотиваційні та ціннісні чинники у процесі оцінювання доказів, які формують свідомість юриста-адміністративіста в аспекті відповідального ставлення до виконуваної роботи. Також науковець підтримував ідею створення законодавчо закріпленої ієрархї̈ доказів як надійного способу уніфікованої оцінювальної 
Стоян А.

Інструменти оцінювання доказів в адміністративному процесі

діяльності [16]. Проте спроби подібної кодифікації залишилися на рівні законопроектів [21], адже такий підхід може зруйнувати незалежність судової влади та порушити концепцію вільного оцінювання доказів, наділивши законодавчу або виконавчу гілку можливістю наперед встановлювати правила щодо переважної доказової сили і значення будь-яких доказів. Використання завищених вимог для відбору на посаду судді також не завжди здатні вичерпно вирішити поставлене завдання, адже важко спрогнозувати, які зміни у житті та характері суб'єкта прийняття рішення можуть відбутися у ході реалізації повноважень, а емоційна детермінанта у процесі формування внутрішнього переконання часто непідконтрольна самому судді. Водночас переконливість одного й того самого доказу може мати різний ступінь для кожного судді залежно від досвіду, загального рівня скептичності та прискіпливості під час оцінювання доказів, а також розуміння законів причинності та зв’язку окремих соціальних явищ [22, с. 28], що спонукає використовувати додаткові гарантії об'єктивізації оцінювальної діяльності.

Стандарти доказування як інструменти формування внутрішнього переконання в адміністративному процесі. Сучасна віха розвитку української процесуалістики має тенденцію залучати зарубіжний оцінювальний інструментарій з метою подолання вищеназваних недоліків. У результаті термін «стандарти доказування» та конкретні його види стали частиною категоріальної сфери пов'язаної зі способом оцінювання доказів як на рівні окремих нормативно-правових актів, так і постанов найвищих судових органів. Водночас одним із викликів для дослідників постало питання примирення та пристосування новітньої категорії до наявного способу оцінювання доказів «за внутрішнім переконанням», аби отримати дивіденди у вигляді розвитку справедливого правосуддя та верховенства права.

Щодо вітчизняної категорії, варто зазначити, що, наприклад, В. Ф. Бойко вважає, що внутрішнє переконання - це світогляд судді, котрий формується 3 народження, протягом усього життя, - тобто це життєвий досвід, загальна культура, юридичний досвід [23, с. 100]. О. П. Цюпак розмежовує власне «переконання» як загальну категорію, елемент правосвідомості, систему ідей та поглядів, яким володіють судді у повсякденному житті, та «внутрішнє переконання», що виникає в процесі розгляду конкретного публічноправового спору. Дослідник також вказує, що на внутрішнє переконання, яке формується на психологічному рівні, впливають різноякісні чинники, зокрема дослідження фабули справи та правових позицій сторін, а також менш очевидні й недоступні сторонньому оку детермінанти - життєвий досвід, громадська думка, особисте ставлення до сторін та інтуїція правника. Сам процес оціночної діяльності судді, за переконанням автора, можливо вмістити у попередню й остаточну оцінку доказового матеріалу [16, с. 181]. Тотожній спосіб поділу зустрічаємо також у праці А. Г. Карапетова та А. С. Косарєва, які, використавши термінологію суб' єктивно-байесіанської моделі, позначили «апріорну суб'єктивну вірогідність» як таку, що передує досвіду та існує у кожного судді інтуїтивно, несвідомо до початку розгляду справи та «суб'єктивну постапостеріорну вірогідність», що формується в результаті дослідження й оцінки представлених доказів [22, с. 20]. Л. В. Мелех додає до наведеного переліку ще й «контрольну оцінку доказів, що проводиться вищими судами під час перегляду справи в апеляційному чи касаційному порядку» [20, с. 170]. Однак, на нашу думку, не зовсім доцільно вносити контрольне оцінювання доказів в один перелік із попередньою та остаточною, адже підстави для такого розмежування різні. Так, залежно від рівня суду оцінювання доказів і справді можливо розглядати як первинне та контрольне, при чому із зазначенням виключно апеляційної інстанції, адже касаційна інстанція реалізує оцінювальні функції у зміненому та обмеженому об'ємі. Два основні етапи оцінювальної діяльності - попередній (апріорний) й остаточний (постапостеріорний) - присутні в кожному оціночному акті судді як його невід'ємні складові незалежно від інстанції. Різниця полягає хіба що в розширенні кола та природи питань, які повинен вирішити суддя вищого суду (оцінити правильність дій судді нижчестоячого суду). Отже, процес оціночної діяльності містить тільки дві складові, а класифікація, в основі якої є ознака інстанційності суду, може включати первинну та контрольну (апеляційну) оцінку доказів.

Також варто звернути увагу на когнітивні помилки, що впливають на суддю під час оцінювання доказів, спричиняючи порушення в процесах обробки інформації, мислення та прийняття рішень, серед яких: «помилка доступності» - переоцінка вірогідності події, яка нещодавно відбулася у житті судді; «викривлена вибірка» - розгляд аномальних справ, що змінюють уявлення про поширеність тих чи інших явищ, «проблема ретроспективного погляду» - упереджене судження судді про можливість особи вчинити іншим, більш правильним чином, коли вже достеменно відомі негативні наслідки раніше обраного рішення [24, с. 73-84]. Також можливі випадки звичайної відсутності віри у певні обставини, якщо вони вступають у протиріччя з власними переконаннями та досвідом, навіть попри представлені докази [25, с. 22]. Отже, чинники на розумовий, психоемоційний стан судді під час оцінювання доказів можливо розподілити на по- 
зитивні та негативні. До позитивних варто віднести особисті якості та чесноти судді (динамічне мислення, швидка реакція, професійна інтуїція, чесність, добросовісність), професіоналізм, компетентність та інші, перелік яких важко назвати вичерпним. Окреме місце посідає також професійна правосвідомість судді, яка, за визначенням Н. М. Юрашевича, становить «систему відчуттів, звичок, уявлень, оцінок, поглядів, теорій, ідей носіїв правосвідомості, які відображають правову дійсність і оціночне ставлення до неї, виконуючи завдяки цьому роль своєрідного регулятора поведінки в юридично важливих ситуаціях». [26, с. 181]. Ускладнюють ухвалення справедливого рішення негативний особистий життєвий досвід, надмірна завантаженість судді, професійна деформація та когнітивні помилки. Отже, в результаті синтезу різноманітних елементів у неоднакових пропорціях вибудовується індивідуальна професійна картина світу кожного судді як «система орієнтації у світі, в частині встановлення правил для мислення, ціннісних орієнтирів та норм поведінки» [27, с. 212].

3 огляду на вищезазначене, варто констатувати велику кількість детермінант, що призводять до зайняття відмінних, а іноді - діаметрально протилежних позицій суддями під час розгляду тотожних питань, що порушує численні засади та принципи судочинства, зокрема рівності перед законом і судом та право на справедливий судовий розгляд. Водночас складнощі, що виникають під час оцінювання доказів мають ідентичний характер незалежно від особливостей правової системи, в якій працює суддя. Однак якщо для континентальної системи права звичною є концепція внутрішнього переконання, то правники загальної системи права сконструювали автентичний спосіб мінімізації, розподілу та усунення судових помилок у вигляді «стандартів доказування» як певного рівня впевненості судді, що має сформуватися в результаті представлення сторонами мінімально достатньої сукупності доказів, необхідної для ухвалення рішення у цивільному або кримінальному процесах [28]. Цікаво, що практика надання дефініції стандартам доказування у країнах походження терміну зводиться до переважної відмови створити уніфіковане визначення через труднощі у одночасному розумінні не тільки професійним корпусом суддів, а й судами присяжних [29]. Так, суддя А. Деннінг в одному з рішень вказав, що усі перепалки щодо визначення змісту стандарту доказування існують лише відносно словесної форми вираження одного й того самого за сутнісною характеристикою поняття [30]. Водночас, слушною є думка П. М. Рабіновича, який зазначає, що міжнародні стандарти доказування відіграють орієнтаційну та юридично-регулюючу роль, а отже, їх тлумачення в рамках окремих галузей має бути відносно уніфікованим [31, с. 18]. Таке висловлювання не втрачає своє значення й принагідно функціонування стандартів доказування в рамках національних правових систем. Отже, з огляду на вищезазначене можливо розподілити науковців кодифікованих систем права на 3 групи: перші - відмовляються надавати визначення стандартам доказування як і їхні зарубіжні колеги [29]. Другі - йдуть шляхом формування універсальної дефініції, яка б відображала міждисциплінарний характер цього інструментарію. Зокрема, професор А. Г. Карапетов вказує, що «стандарт доказування це мінімальний рівень впевненості, необхідний для того, щоб визнати факт доведеним, і граничний рівень сумнівів, що поєднується 3 таким визнанням» [22]. А. С. Степаненко зазначає, що «стандарт доказування є певним критерієм (порогом) прийняття рішення для суб'єкта ухвалення рішення, встановлюючи певний рівень (міру) доведеності для визнання певного факту існуючим» [32]. Г. Р. Крет також розвиває доктринальне визначення поняття «стандартів доказування», а саме: за рахунок врахування в ньому таких ознак, як об'єктивність, соціальну зумовленість, динамічність, системність і загальнообов'язковість, а також розмежовує «стандарти доказування» та «стандарти доказаності» [33].

Третя група вчених включає специфічні ознаки відповідної галузі у процесі розроблення поняття. Так, Х. Р. Слюсарчук визначає кримінальний процесуальний стандарт доказування «як кількісну та якісну характеристику доказування, з виділенням спеціальних суб'єктів в рамках кримінального провадження, які оцінюють докази» [34].

Таким чином, приєднуючись до останньої групи вчених, видається необхідним створити уніфіковану галузеву дефініцію «стандартів доказування» для її використання як на теоретичному, так і праксеологічному рівнях адміністративного процесу. Водночас у процесі створення визначення не варто остерігатися труднощів, які виникали у країнах англо-американської системи права щодо ідентичного розуміння суб'єктами прийняття рішення змісту стандартів доказування, зокрема з огляду на особливості притаманних вітчизняному адміністративному процесуальному праву. Першою такою рисою є відсутність інституту присяжних в адміністративному процесі, існування якого в країнах загального права здебільшого призвело до відмови надати єдину дефініцію стандартів доказування через ускладнене розуміння та практичне застосування оціночної категорії останніми. Крім цього, національне адміністративне судочинство повністю знаходиться в руках суддів, професіоналізм та компетентність яких передбачають вміння користуватися 
Стоян А.

Інструменти оцінювання доказів в адміністративному процесі

наданим інструментарієм за призначенням, а тому створення галузевої дефініції є необхідним базисом для належного виконання їхніх повноважень та функцій. По-друге, власне природа стандартів доказування наразі виявляє себе переважно як теоретична конструкція в рамках адміністративного процесу. В той час як у країнах загальної системи права практичне значення стандартів є первинним та судді його використовують за замовчування, а можливо навіть укорінилося на рівні підсвідомості внаслідок багаторазового використання протягом тривалого часу. Наша держава також прагне надати стандартам доказування ідентичний статус, що підтверджується постійним нагадуванням Верховним Судом у своїх Постановах [35] про важливість та необхідність використання «стандартів доказування» при відправленні правосуддя судами усіх рівнів. Однак відсутність саме прямого згадування у Кодексі адміністративного судочинства України про поняття та види стандартів доказування навряд чи можливо назвати виявом позитивної динаміки в даному напрямку, адже юридична техніка здатна якнайкраще відобразити політичну волю законодавця.

Висновки. 3 огляду на вищезазначене пропонується розуміти стандарти доказування як інструмент об’єктивізації розумових (логічних) процесів судді під час оцінювання доказів за внутрішнім переконанням з метою справедливого вирішення публічно-правового спору та уніфікації судової практики, а саме: процесу ухвалення рішень за тотожних обставин або у типових категоріях справ. Водночас інструментами оцінювання доказів є допоміжні елементи об'єктивізації мисленнєвого процесу судді у вигляді стандартів доказування, що застосовуються на шляху формування знання про факти об' єктивної соціальної дійсності, забезпечуючи досягнення та існування такого стану внутрішнього переконання, яке дозволяє судді ухвалити справедливе рішення по справі. Видами інструментів оцінювання доказів у адміністративному процесі є «баланс вірогідностей», «ясні та переконливі докази», «поза розумним сумнівом».

Водночас, окрім вищенаведеної дефініції, у КАСУ також мають відображатися інші новели. Так, видається вмотивованим внесення змін до Кодексу у ст.90 «Оцінка доказів», яку пропонується доповнити формулюванням про те, що «суд оцінюючи докази за внутрішнім переконанням повинен послуговуватися стандартами доказування». Таким чином стандарти доказування отримають законодавчий статус інструменту об'єктивізації розумових процесів судді під час оцінювання доказів за внутрішнім переконанням, покращивши якість відправлення правосуддя у адміністративному процесі. Кожен із видів інструментів варто розуміти як шлях або спосіб формування внутрішнього переконання. Окрема стаття у Кодексі має бути присвячена переліку стандартів доказування, які суддя має використовувати під час відправлення правосуддя. Позиція, відповідно до якої потребам адміністративного судочинства мають слугувати саме 3 стандарти доказування - «баланс вірогідностей» як найнижчий, «чіткі та переконливі докази» як проміжний та «поза розумним сумнівом» як найвищий була відстояна у попередніх публікаціях [36]. Виправданим видається також створення загальних правил (відправних точок) для практичної діяльності судді 3 метою уніфікації випадків видозміни стандарту доказування. Зазначені правила неодмінно мають бути засновані на таких параметрах, як категорія спору або вид суб'єкта адміністративного провадження до якого висувається стандарт, а також із обов'язковим урахуванням конкретно-індивідуалізованих наслідків для кожної зі сторін.

Окрім іншого, редагування потребує й ч. 4 ст. 246 Кодексу, відповідно до якої структура судового рішення мала бути доповнена пунктом про необхідність зазначення обраного стандарту доказування, керуючись яким суддя зробив висновок про достатність доказів, задовольнивши або відмовивши у позові. Таке зазначення полегшить роботу суддям апеляційної інстанції, адже дасть змогу оцінити правильність підбору стандарту залежно від обставин та співвіднести докази, що є в основі оскарженого рішення, через призму власних відчуттів. В подальших наукових розвідках більш детальної уваги потребує дослідження співвідношення концепції внутрішнього переконання та стандартів доказування в рамках адміністративного процесу.

\section{Список використаних джерел}

1. Фурса С., Цюра Т. Докази і доказування у цивільному процесі : наук.-практ. посіб. Київ, 2005.256 с.

2. Щербаков С. В. Теория доказательств и доказывания: содержание и проблемы : монография. Архангельск, 2007. 263 с.

3. Барабаш Т. М. Моніторинг теорії доказування у процесуальному праві України. Судова апеляція. 2009. № 2 (15). C. 6-15. URL: http://dspace.nbuv.gov.ua/bitstream/handle/123456789/13976/01-Barabash.pdf (дата звернення: 12.08.2021). 
4. Авраменко О. Загальна характеристика процедури дослідження доказів в адміністративному судочинстві. Наукові записки. Сер. : Право. 2019. Вип. 7. Спецвипуск. С. 112-116. URL: https://www.cuspu.edu. ua/ images/nauk_zapiski/pravo/7_spec_2019/Авраменко.pdf (дата звернення: 14.08.2021).

5. Ківалов С. В., Осадчий А. Ю., Закаленко О. В. Адміністративний процес (загальна частина) : навч. посіб. (для здобувачів вищої освіти денної форми навчання). Одеса, 2019. 224 с.

6. Постанова КГС ВС від 14.12.2018 у справі № 914/809/18. C. 14. URL: https://supreme.court.gov.ua/ userfiles/media/new_folder_for_uploads/supreme/Chymak.pdf (дата звернення: 17.08.2021).

7. Поворознюк М. І. Адміністративний позов у системі засобів захисту прав громадянина у сфері публічно-правових відносин. Часопис Київського університету права. 2017. № 3. С. 137-145.

8. Кодекс адміністративного судочинства України від 06.07.2005 No 2747-IV. URL: https://zakon.rada.gov. ua/laws/show/2747-15 (дата звернення: 18.08.2021).

9. Кротюк О. В. Принцип офіційного з'ясування всіх обставин у справі та його реалізація в адміністративному судочинстві України : автореф. дис. ... канд. юрид. наук: 12.00.07. Київ. 2013. 18 с.

10. Бандурка О. М. Адміністративний процес України : монографія. Харків : ХНУВС, Майдан, 2019.422 с. URL: http://dspace.univd.edu.ua/xmlui/bitstream/handle/123456789/7669/Bahdurka_admin_proces_2019. pdf?sequence=1\&isAllowed=y (дата звернення: 02.08.2021).

11. Кримінальний кодекс України від 05.04.2001 № 2341-III. URL: https://zakon.rada.gov.ua/laws/show/234114\#Техt (дата звернення: 01.09.2021).

12. Постанова Верховного суду України у справі № 922/51/20 від 29 січня 2021 року. URL: https://reyestr. court.gov.ua/Review/94517830?fbclid=IwAR3-HdF9CsVL4e26vKX3UiaVbYy4p2cg07vV1q4fqWHzIEAv dl8JtrUNmJA (дата звернення: 22.08.2021).

13. Пащенко К. С. Нормативне гарантування оцінки доказів в адміністративному судочинстві:вітчизняний та зарубіжний досвід. 2/2020. The scientific papers of the legislation institute of the Verkhovna Rafa of Ukraine. C. 37-46. URL: https://instzak.com/index.php/journal/article/download/1791/1676/ (дата звернення: 26.08.2021).

14. Барабаш Т. М. Категорія «суб'єкт» у кримінальному процесі України. Наукові записки інституту законодавства Верховної Ради Украӥни. 2012. № 3. С.110-114.

15. Дубенко О. М. Доказування в адміністративному судочинстві України : автореф. дис. ...канд. юрид. наук. Ірпінь, 2010. 20 с.

16. Цюпак О. П. Оцінка доказів в адміністративному судочинстві : правовий та логічний аспекти. $B i-$ сник Харківського національного університету внутрішніх справ. 2014. № 2. C. 179-186. URL: http://www.irbis-nbuv.gov.ua/cgi-bin/irbis_nbuv/cgiirbis_64.exe?C21COM=2\&I21DBN=UJRN\& P21DBN=UJRN\&IMAGE_FILE_DOWNLOAD=1\&Image_file_name=PDF/VKhnuvs_2014_2_24.pdf (дата звернення: 02.09.202立).

17. Немченко В. О. Акмеологія суддівської діяльності в адміністративному процесі. Форум права. 2013. № 2. C. 402-406. URL: http://www.irbisnbuv.gov.ua/cgibin/irbis_nbuv/cgiirbis_64.exe?C21COM=2\&I2 $1 \mathrm{DBN}=\mathrm{UJRN} \& \mathrm{P} 21 \mathrm{DBN}=\mathrm{UJRN} \& I M A G E \_F I L E \_D O W N L O A D=1 \&$ Image_file_name $=\mathrm{PDF} / \mathrm{FP}$ _index. htm_2013_2_62.pdf. (дата звернення: 24.08.2021).

18. Курыльов С. В. Основы теории доказывания в советском правосудии. Минск, 1969. 204 с.

19. Матюшин Б. Т. Общие вопросы оценки доказательств в судопроизводстве. Хабаровск : Прогресс, 1987. $141 \mathrm{c.}$

20. Мелех Л. В. Проблеми оцінки доказів у процесі доказування. Вісник Луганського державного університету внутрішніх справ імені Е. О. Дідоренка. Проблеми цивільного, трудового, екологічного та госпрдарського права. Розділ IV.4.2015. С. 166-177. URL: https://journal.lduvs.lg.ua/index.php/journal/ article/download/712/642/ (дата звернення: 08.08.2021).

21. Про схвалення Концепції запобігання корупції у системі судів загальної юрисдикції : проект Закону України від 17.03.2009 No 4220. URL: http://search.ligazakon.ua/1_doc2.nsf/link1/JF39800I.html (дата звернення: 04.09.2021)

22. Карапетов А. Г., Косарев А. С. Стандарты доказывания: аналитическое и эмпирическое исследование. Вестник экономического правосудия Российской Федерации. Приложение к Ежемесячному журналу. 2019. № 6 (63). С. 1-96. URL: https://m-logos.ru/img/Article-about-standards.pdf (дата звернення: 13.08.2021).

23. Бойко В. Ф. Судова реформа в Україні: стан і перспективи : [навч. посібник]. Бойко В. Ф. Київ : МАУП, 2004. $176 \mathrm{c}$. 
24. Карапетов А. Г. Єкономический анализ права. Москва, 2016. С. 73-84

25. Владимиров Л. Е. Учение об уголовных доказательствах. Тула, 2000. С. 22.

26. Юрашевич Н. М. Эволюция понятия правового сознания. Известия вузов. Правоведение. 2004. № 2. С. $178-187$.

27. Кумеда Т. А. Концепт «картина світу» як об’єкт гуманітарних досліджень. Гілея: зб. наук. пр. / голов. ред. В. М. Вашкевич. Київ : ВІР УАН, 2012. Вип. 65 (№ 10). С. 210-214.

28. Merriam-Webster (n.d.). Standard of proof. In Merriam-Webster.com legal dictionary. Retrieved July 7, 2021. URL: https:/www.merriam-webster.com/legal/standard\%20of\%20proof дата звернення: 28.08.2021).

29. Безносюк А. М. Доведеність поза розумним сумнівом та достовірність як стандарти доказування у кримінальному процесі України. Судова апеляиія. 2014. № 3(36). С. 23-28.

30. Bater v. Bater CA ([1950] 2 ALL ER 458). URL: http://swarb.co.uk/bater-v-bater-CA-1950 (дата звернення: 28.08.2021).

31. Рабінович П., Венецька О. Міжнародні стандарти прав людини: загальні ознаки, класифікація. Вісник Національної академї правових наук України. 2012. № 4 (71). С. 18-28.

32. Степаненко А. С. Стандарт доказування «поза розумним сумнівом» у кримінальному провадженні : дис. ... канд. юрид. наук: 12.00.09. Одесса, 2017. 234 с. URL: http://dspace.onua.edu.ua/bitstream/ handle/11300/ 7009/Дисертація\%20Степаненко\%20A.C..pdf?sequence=4\&isAllowed=у (дата звернення: 05.08.2021).

33. Крет Г. Р. Міжнародні стандарти доказування у кримінальному процесі України: теоретико-правові та практичні основи : дис. ... доктора юрид. наук: 12.00.09. Одеса, 2020. 530 c. URL: http://dspace.onua.edu. ua/bitstream/handle/11300/13756/Дисертація\%20-\%20Крет\%20Г.P..pdf?sequence=3\&isAllowed=y (дата звернення: 07.08.2021).

34. Слюсарчук Х. Р. До питання про сутність поняття «стандарти доказування». Проблеми державотворення і захисту прав людини в Україні: матеріали XXI звітної науково-практичної конференцї (Львів): Юридичний факультет Львівського начіонального університету імені Івана Франка. Львів, 2015. 258-261. URL: https://law.lnu.edu.ua/wp-content/uploads/2016/02/Дисертація-Слю.pdf (дата звернення: 07.08.2021).

35. Постанова Верховного суду України у справі № 922/51/20 від 29 січня 2021 року. URL: https://reyestr. court.gov.ua/Review/94517830?fbclid=IwAR3-HdF9CsVL4e26vKX3UiaVbYy4p2cg07vV1q4fqWHzIEAv dl8JtrUNmJA(дата звернення: 14.08.2021).

36. Стоян А. В. Триступенева градація стандартів доказування в адміністративному процесі. Форум права. 2021. № 66(1). С. 25-36. URL: http://doi.org/10.5281/zenodo.4486520 (дата звернення: 03.09.2021).

\section{References}

1. Fursa, S., Tsiura, T. (2005). Dokazy i dokazuvannia u tsyvilnomu protsesi [The evidence and proof in the civil law]. Kyiv [in Ukrainian].

2. Shcherbakov, S.V. (2007). Teoryia dokazatelstv y dokazivanyia: soderzhanye y problem [The theory of the evidence and proof]. Arkhanhelsk [in Russian].

3. Barabash, T.M. (2009). Monitorynh teorii dokazuvannia u protsesualnomu pravi Ukrainy [Monitoring the theory of proof in procedural law of Ukraine]. Sudova apeliatsiia - Court appeal, 2 (15) [in Ukrainian]. Retrieved from http://dspace.nbuv.gov.ua/bitstream/handle/123456789/13976/01-Barabash.pdf [in Ukrainian].

4. Avramenko, O. (2019). Zahalna kharakterystyka protsedury doslidzhennia dokaziv $v$ administratyvnomu sudochynstvi [General characteristics of the procedure of examination of evidence in administrative proceeding]. Scientific notes. Series: Law. Retrieved from https:/www.cuspu.edu.ua/images/nauk_zapiski/ pravo/7_spec_2019/Avramenko.pdf [in Ukrainian].

5. Kivalov, S. V., Osadchyi, A. Yu., Zakalenko, O. V. (2019). Administratyvnyi protses [The administrative process] (zahalna chastyna): navchalnyi posibnyk (dlia zdobuvachiv vyshchoi osvity dennoi formy navchannia). Odesa. [in Ukrainian].

6. Postanova KHS VS u spravi №914/809/18 [Resolution of the Court of Ukraine]. (2018 December 12). Retrieved from https://supreme.court.gov.ua/userfiles/media/new_folder_for_uploads/supreme/Chymak.pdf [in Ukrainian].

7. Povorozniuk, M. I. (2017) Administratyvnyi pozov u systemi zasobiv zakhystu prav hromadianyna u sferi publichno-pravovykh vidnosyn [Administrative lawsuit in the system of means of protection of civil rights in 
the field of public relations]. Chasopys Kyivskoho universytetu prava - Journal of Kyiv University of Law, 3, 137-145 [in Ukrainian].

8. Kodeks administratyvnoho sudochynstva Ukrainy [Code of Administrative Procedure of Ukraine]. (2005, June 05). Retrieved from https://zakon.rada.gov.ua/laws/show/2747-15 [in Ukrainian].

9. Krotiuk, O. V. (2013). Pryntsyp ofitsiinoho ziasuvannia vsikh obstavyn u spravi ta yoho realizatsiia v administratyvnomu sudochynstvi Ukrainy [The principle of official clarification of all the circumstances of the case and its implementation in the administrative proceedings of Ukraine]. Extended abstract of candidate's thesis. Kyiv [in Ukrainian].

10. Bandurka, O. M. (2019). Administratyvnyi protses [The administrative process]. Kharkiv: KhNUVS, Maidan. Retrieved from http://dspace.univd.edu.ua/xmlui/bitstream/handle/123456789/7669/Bahdurka_admin proces_2019.pdf?sequence $=1 \&$ isAllowed $=\mathrm{y}$ [in Ukrainian].

11. Kryminalnyi kodeks Ukrainy [Criminal Code of Ukraine] (2001, April 05). Retrieved from https://zakon.rada. gov.ua/laws/show/2341-14\#Text [in Ukrainian].

12. Postanova Verkhovnoho sudu Ukrainy [Resolution of the Supreme Court of Ukraine] u spravi № 922/51/20 (2021 January 29). Retrieved from https://reyestr.court.gov.ua/Review/94517830?fbclid=IwAR3-HdF9CsV L4e26vKX3UiaVbYy4p2cg07vV1q4fqWHzIEAvdl8JtrUNmJA [in Ukrainian].

13. Pashchenko, K.S. (2020). Normatyvne harantuvannia otsinky dokaziv v administratyvnomu sudochynstvi:vitchyznianyi ta zarubizhnyi dosvid [Normative guarantee of evidence evaluation in administrative proceedings: domestic and foreign experience]. The scientific papers of the legislation institute of the Verkhovna Rafa of Ukraine [in Ukrainian].

14. Barabash, T. M. (2012). Katehoriia «subiekt» u kryminalnomu protsesi Ukrainy [The category of «subject» in the criminal process of Ukraine]. Naukovi zapysky instytutu zakonodavstva Verkhovnoi Rady Ukrainy Scientific notes of the Institute of Legislation of the Verkhovna Rada of Ukraine. [in Ukrainian].

15. Dubenko, O. M. (2010). Dokazuvannia vadministratyvnomu sudochynstvi Ukrainy [Evidence in administrative proceedings of Ukraine]. Extended abstract of candidate's thesis. Irpin [in Ukrainian].

16. Tsiupak, O. P. (2014). Otsinka dokaziv v administratyvnomu sudochynstvi : pravovyi ta lohichnyi aspekty [Evaluation of evidence in administrative proceedings: legal and logical aspects]. Visnyk Kharkivskoho natsionalnoho universytetu vnutrishnikh sprav - Bulletin of Kharkiv University of Internal Affairs, 2, 179-186. Retrieved from http://www.irbis-nbuv.gov.ua/cgi-bin/irbis_nbuv/cgiirbis_64.exe?C21COM=2\&I21DBN=UJ RN\&P21DBN=UJRN\&IMAGE_FILE_DOWNLOAD=1\&Image_file_name=PDF/VKhnuvs_2014_2_24. pdf [in Ukrainian].

17. Nemchenko, V. O. (2013). Akmeolohiia suddivskoi diialnosti v administratyvnomu protsesi [Acmeology of judicial activity in the administrative process]. Forum prava - Forum of law, 2. 402-406. Retrieved from. $\mathrm{http}: / /$ www.irbisnbuv.gov.ua/cgibin/irbis nbuv/cgiirbis 64.exe?C21COM=2\&I21DBN=UJRN\&P21DBN= UJRN\&IMAGE_FILE_DOW $. \geq \ldots \geq \geq>>>\geq L O A D=1 \&$ Image_file_name=PDF/FP_index.htm_2013_2_62. pdf. [in Ukrainian].

18. Kurylov, S. V. (1969). Osnovy teorii dokazyvaniya v sovetskom pravosudii [Foundations of the theory of proof in Soviet justice]. Minsk [in Russian].

19. Matyushin, B. T. (1987). Obshchie voprosy ocenki dokazatel'stv v sudoproizvodstve [General questions of the assessment of evidence in legal proceedings]. Habarovs: Progress [in Russian].

20. Melekh, L.V. (2015). Problemy otsinky dokaziv u protsesi dokazuvannia [Problems of evaluating evidence in the process of proving]. Visnyk Luhanskoho derzhavnoho universytetu vnutrishnikh sprav imeni E.O. Didorenka. Problemy tsyvilnoho, trudovoho, ekolohichnoho ta hosprdarskoho prava-Bulletin of Luhansk State University of Internal Affairs named after E.O. Didorenko, 166-177). Retrieved from: https://journal. lduvs.lg.ua/index.php/journal/article/ download/712/642/ [in Ukrainian].

21. Pro skhvalennia Kontseptsii zapobihannia koruptsii u systemi sudiv zahalnoi yurysdyktsii: proekt Zakonu Ukrainy [On approval of the Concept of prevention of corruption in the system of courts of general jurisdiction: draft Law of Ukraine]. March, 17 2009. Retrieved from http://search. ligazakon.ua/1_doc2.nsf/ link1/JF39800I.html. [in Ukrainian].

22. Karapetov, A. G, Kosarev, A. S. (2019). Standarty dokazyvaniya: analiticheskoe i empiricheskoe issledovanie [Standards of proof: analytical and empirical research]. Bulletin of Economic Justice of the Russian Federation, 1-96. Retrieved from https://m-logos.ru/img/Article-about-standards.pdf [in Russian].

23. Boiko, V. F. (2004). Sudova reforma v Ukraini: stan i perspektyvy [Judicial reform in Ukraine: status and prospects]. Kyiv: MAUP [in Ukrainian]. 
24. Karapetov, A. G. (2016). Ekonomicheskij analiz prava [Economic analysis of law]. Moscow [in Russian].

25. Vladimirov, L. E. (2000). Uchenie ob ugolovnyh dokazatel'stvah [The doctrine of criminal evidence]. Tula [in Russian].

26. Yurashevich, N. M. (2004). Evolyuciya ponyatiya pravovogo soznaniya [Evolution of the concept of legal consciousness]. Yzvestia vuzov. Pravovedenie - University review. Law, 2, 178-187 [in Russian].

27. Kumeda, T. A. (2012). Kontsept «kartyna svitu» yak obiekt humanitarnykh doslidzhen [The concept of «picture of the world» as an object of humanitarian research]. Kyiv: VIR UAN, 210-214 [in Ukrainian].

28. Merriam-Webster, (n.d.). Standard of proof. In Merriam-Webster.com legal dictionary. July 7, 2021. Retrieved from https://www.merriam-webster.com/legal/standard\%20of\%20proof [in English].

29. Beznosiuk, A. M. (2014). Dovedenist poza rozumnym sumnivom ta dostovirnist yak standarty dokazuvannia u kryminalnomu protsesi Ukrainy [Proof beyond a reasonable doubt and reliability as standards of proof in the criminal process of Ukraine]. Sudova apeliatsiia - Judicial appeal, 3(36), C. $23-28$ [in Ukrainian].

30. Bater v. Bater CA (1950). 2 ALL ER 458). Retrieved from http://swarb.co.uk/bater-v-bater-CA- 1950/ [in English].

31. Rabinovych, P. \& Venetska, O. (2012). Mizhnarodni standarty prav liudyny: zahalni oznaky, klasyfikatsiia [International human rights standards: general features, classification]. Visnyk Natsionalnoi akademii pravovykh nauk Ukrainy - Bulletin of National Academy of Legal Sciences, 4 (71), 18-28 [in Ukrainian].

32. Stepanenko, A. S. (2017). Standart dokazuvannia «poza rozumnym sumnivom» u kryminalnomu provadzhenni [Standard of proof «beyond a reasonable doubt»]: Candidate's thesis. Odessa. Retrieved from http://dspace.onua.edu.ua/bitstream/handle/11300/7009/Дисертація\%20Степаненко\%20A.C.. pdf? sequence $=4 \&$ isAllowed $=y$ [in Ukrainian].

33. Kret, H. R. (2020). Mizhnarodni standarty dokazuvannia u kryminalnomu protsesi Ukrainy: teoretykopravovi ta praktychni osnovy [International standards of proof in the criminal process of Ukraine: theoretical, legal and practical bases]: Doctor's thesis. Odesa. Retrieved from http://dspace.onua.edu.ua/bitstream/ handle/11300/13756/Дисертація\%20-\%20Крет\%20Г.P..pdf?sequence=3\&isAllowed=y [in Ukrainian].

34. Sliusarchuk, Kh. R. (2015). Do pytannia pro sutnist poniattia «standarty dokazuvan-nia» [On the essence of the concept of «standards of proof»]. Problemy derzhavotvorennia i zakhystu prav liudyny v Ukraini: materialy XXI zvitnoi naukovo-praktychnoi konferentsii (Lviv): Yurydychnyi fakultet Lvivskoho natsionalnoho universytet $u$ imeni Ivana Franka, 258-261). Retrieved from https://law.Inu.edu.ua/wp-content/uploads/2016/02/ Дисертація-Слю.pdf [in Ukrainian].

35. Postanova Verkhovnoho sudu Ukrainy u spravi № 922/51/20 [Resolution of the Supreme Court of Ukraine in case № 922/51/20]. (2021, January 29). Retrieved from https://reyestr.court.gov.ua/ Review/94517830?fbclid=IwAR3-HdF9CsVL4e26vKX3UiaVbYy4p2cg07vV1q4fqWHzIEAvd18JtrUNm JA [in Ukrainian].

36. Stoian, A. V. (2021). Trystupeneva hradatsiia standartiv dokazuvannia v administratyvnomu protsesi [Threestage gradation of standards of proof in the administrative process]. Forum Prava - Forum of law, 66(1), 25-36 URL: Retrieved from http://doi.org/10.5281/zenodo.4486520 [in Ukrainian]. 